\title{
FCRL4 wt Allele
}

National Cancer Institute

\section{Source}

National Cancer Institute. FCRL4 wt Allele. NCI Thesaurus. Code C97593.

Human FCRL4 wild-type allele is located in the vicinity of $1 \mathrm{q} 21$ and is approximately $24 \mathrm{~kb}$ in length. This allele, which encodes Fc receptor-like protein 4 , may play a role in the modulation of B cell receptor signaling. A chromosomal translocation t(1;1)(p36.3; q21.1-

2) involves this gene and is associated with non-Hodgkin lymphoma. A second translocation $\mathrm{t}(1 ; 14)(\mathrm{q} 21 ; \mathrm{q} 32)$ of this gene and the IGHA1 gene is associated with multiple myeloma. 